\title{
The unusual association of Graves' disease, chronic spontaneous urticaria, and premature ovarian failure: report of a case and HLA haplotype characterization
}

\author{
A associação incomum entre doença de Graves, \\ urticária crônica idiopática e insuficiência ovariana \\ prematura: relato de caso clínico e tipagem HLA
}

Rosaria Maddalena Ruggeri', Giuseppe Vita'2, Anna Grazia D'Angelo³, Paolina Quattrocchi ${ }^{3}$, Rosaria Certo', Salvatore Benvenga ${ }^{1,4}$, Salvatore Cannavò', Sebastiano Gangemi ${ }^{3,5}$

${ }^{1}$ Unit of Endocrinology, Department of Clinical and Experimental Medicine, University of Messina, Italy ${ }^{2}$ Unit of Tissue Typing, Department of Pathology and Experimental Microbiology, University of Messina, Italy ${ }^{3}$ School and Unit of Allergy and Clinical Immunology, Department of Clinical and Experimental Medicine, University of Messina, Italy ${ }^{4}$ Interdepartmental Program of Molecular and Clinical Endocrinology \& Women's Health; A.O.U. Policlinico "G. Martino", Messina Italy ${ }^{5}$ Institute of Biomedicine and Molecular Immunology-National Research Council, Palermo, Italy

Correspondence to: Rosaria Maddalena Ruggeri Dipartimento di Medicina Clinica e Sperimentale, Unità di Endocrinologia

Padiglione $\mathrm{H}, 4$ piano - $\mathrm{AOU}$

Policlinico "G. Martino"

via Consolare Valeria, 1

98125 - Messina, Italy

rmruggeri@unime.it

Received on July/11/2013

Accepted on Aug/7/2013

\begin{abstract}
SUMMARY
Chronic spontaneous urticaria (CSU), defined as the occurrence of spontaneous wheals for more than six weeks, has been associated with autoimmune diseases. Herein, we report the unusual association of CSU, Graves' disease, and premature ovarian failure. Human leukocyte antigen (HLA) studies were performed. A 36-year-old woman presented symptoms and signs of hyperthyroidism for three months. In the same period, the patient complained of widespread urticarial wheals, intensely itchy, and poorly responsive to therapy with antihistaminic agents. Hyperthyroidism was confirmed biochemically, and treatment with methimazole was started. As hyperthyroidism improved, a marked improvement in her urticaria was also observed. However, the patient continued to complain of amenorrhea. Endocrine evaluation, at the age 38, was consistent with premature ovarian failure. This is the first report of coexistence of GD, CSU, and POF. The genetic background of such unusual association is a specific combination of HLA. Arq Bras Endocrinol Metab. 2013;57(9):748-52
\end{abstract}

\begin{abstract}
SUMÁRIO
A urticária crônica idiopática, caracterizada pelo aparecimento de pápulas espontâneas e persistentes por pelo menos seis semanas, tem sido associada a doenças autoimunes. Apresentamos aqui o caso da associação incomum entre urticária crônica idiopática, doença de Graves e falência ovariana prematura. Foram conduzidos estudos de tipagem HLA. Uma mulher de 36 anos apresentou sinais e sintomas de hipertireoidismo por três meses. No mesmo período, a paciente queixou-se do aparecimento de pápulas urticariformes generalizadas que coçavam intensamente e não eram responsivas ao tratamento com anti-histamínicos. $\mathrm{O}$ hipertireoidismo foi confirmado bioquimicamente, e o tratamento com metimazol foi iniciado. Assim que os valores hormonais se normalizaram, observou-se uma melhoria significativa do quadro de urticária. No entanto, a paciente continuou a apresentar amenorreia. A avaliação endocrinológica, com a idade de 38 anos, mostrou falência ovariana prematura. Este é o primeiro caso de associação entre doença de Graves, urticária idiopática crônica e falência ovariana prematura. A base genética dessa associação incomum é representada por combinações específicas de haplótipos HLA. Arq Bras Endocrinol Metab. 2013;57(9):748-52
\end{abstract}

\section{INTRODUCTION}

$\mathrm{C}$ hronic urticaria is a common condition characterized by itchy wheals and flare-type skin reactions (hives) lasting more than six weeks ( 1 ). The term idiopathic is used when the causes remain unknown, which occurs in about $75 \%$ of patients. According to the last European consensus guidelines, the term chronic "spontaneous" urticaria (CSU) is used instead of the previous term, "idiopathic", to emphasize that wheals develop independently of identified external stimuli (2). 
At any given time, $0.5 \%-1.0 \%$ of the population is suffering from CSU (1). Nevertheless, its etiopathogenesis is not well understood yet $(1,2)$. At least in a subset of patients, CSU has an autoimmune basis, as demonstrated by the presence of antibodies against the $\alpha$-subunit of the high-affinity $\operatorname{IgE}$ receptor $\left(\mathrm{Fc}_{\varepsilon} \mathrm{RI}_{\alpha}\right)$, or against IgE itself in the serum of $30 \%-40 \%$ of such patients (1$3)$. The association of CSU with thyroid autoimmunity further supports its autoimmune origin (4). CSU patients frequently suffer from Hashimoto's thyroiditis and increased serum levels of anti-thyroid antibodies were reported in $10 \%$ to $33 \%$ CSU patients $(4,5)$. Coexisting Graves' disease (GD) has been reported less frequently than $\mathrm{HT}$, with an estimated prevalence ranging from $1 \%$ to $4 \%$ (6). Moreover, CSU may also be associated with autoimmune conditions other than thyroid diseases (7). Herein, we report the unusual association of GD, CSU, and premature ovarian failure (POF) of autoimmune origin. Human leukocyte antigen (HLA) studies were performed.

\section{PATIENT}

A 36-year-old woman referred to our outpatient clinic because of fatigue, palpitations, tremors, nervousness and irritability, insomnia, oligo-amenorrhea, sweating, and weight loss for three months. In the same period, she complained of the repeated occurrence of shortlived cutaneous wheals accompanied by redness and itching. Individual wheals lasted less than 24 hours and were poorly responsive to regular antihistamine therapy. GD was diagnosed based on clinical symptoms/ signs, TSH level of $<0.001 \mathrm{mIU} / \mathrm{L}$ (normal values, 0.27-4.2) with elevated free triiodothyronine (FT3, $17.39 \mathrm{pg} / \mathrm{mL}$, normal values, 2-4.4) and free thyroxine (FT4, $38.3 \mathrm{pmol} / \mathrm{L}$, normal values, 12-22), and positivity of anti-TSH-receptor antibodies (TRAb, 19 $\mathrm{IU} / \mathrm{L}$, normal values, $<1.5$ ), as well as of anti-thyroid peroxidase antibodies (TPOAb, $178 \mathrm{U} / \mathrm{L}$; normal values, < 35). Ultrasound (US) examination showed a diffuse enlargement of the thyroid, associated with hypoechogenicity and increased vascularity. The ${ }^{131} \mathrm{I}$ thyroid scan revealed an enlarged gland with diffuse increased uptake of radio-iodine at 6 and 24 hours. Therapy with methimazole (MMI, $30 \mathrm{mg} /$ day) was started, with progressive attenuation of symptoms and signs of thyrotoxicosis and normalization of FT3 and FT4 values. As thyroid function improved, a marked improvement in her urticaria was also observed, and it was readily controlled by antihistamine therapy at conventional doses. When thyroid function returned to normal, urticaria was only minimally evident, and antihistamine therapy was progressively reduced until withdrawal. The patient was maintained on MMI therapy for about 12 months, and no relapse of both hyperthyroidism and CSU occurred, even when MMI therapy was discontinued. The patient continued to complain of menstrual irregularities, and was treated with oestroprogestative (EP) by her gynecologist. Discontinuation of EP was always followed by amenorrhea. Biochemical evaluation in amenorrhea, at the age 38 , showed increased levels of serum FSH $(85 \mathrm{mIU} / \mathrm{L})$ and $\mathrm{LH}$ $(52.10 \mathrm{mIU} / \mathrm{L})$ and low serum estradiol $(3 \mathrm{pmol} / \mathrm{L})$. Serum FT4 and FT3 were normal, as was TSH (1.5 $\mathrm{mIU} / \mathrm{L})$ and TRAB were negative (1.0 IU/L). Serum levels of anti-Mullerian hormone were low $(0.1 \mathrm{ng} / \mathrm{mL}$; 0-2.4). Pelvic US demonstrated small-sized ovaries, deprived of follicles. The karyotype was 46XX. Steroidcell autoantibodies - the only anti-ovarian antibodies tested in our laboratory by immunofluorescence - were negative, as often observed in patients without associated adrenal autoimmunity. All findings were consistent with premature ovarian failure (POF), of likely autoimmune origin, and treatment with EP was resumed. Two years later, during a stressful period, the patient developed again urticaria persisting for more than 8 months and poorly responsive to antihistamine therapy (fexofenadine $180 \mathrm{mg} /$ day and cinnarizine $75 \mathrm{mg}$ /day). Pertinent biochemical data are presented in table 1 . The autologous serum skin test (ASST) - performed by administering an intradermal injection of $0.05 \mathrm{~mL}$ of fresh, undiluted serum obtained by centrifugation of the patient's blood sample - was positive, strongly suggesting an autoimmune pathogenesis of CSU (8). The patient was screened for both non-organ-specific and organ-specific autoantibodies, all but anti-thyroid negative (Tables 1 and 2). Six months after the onset of urticaria, the patient developed symptomatic hyperthyroidism, confirmed biochemically (Table 2). Serum levels of TRAB and TPOAb were increased, and TgAb became positive. Again, urticarial symptoms quickly ameliorated as methimazole treatment was started, and the patient became euthyroid. We studied the patient human leukocyte antigen (HLA) expression on lymphocytes and genomic haplotype (see supplementary data for methodological details). Genomic and serologic HLA haplotype of our patient is shown in table 3. 
Of note, HLA-B44 and HLA DR3-DQ2-DQ7 confer high predisposing risk of CSU (9) and GD (10-12), respectively, while the HLA B8/DR3(DR52) and HLA $\mathrm{DRB1}{ }^{*} 11 / \mathrm{DQB1}{ }^{*} 03$ haplotype is reported as predisposing for autoimmune POF $(13,14)$.

Table 1. Serum biochemical data of our patient at the time of the second episode of urticaria*

\begin{tabular}{|c|c|c|}
\hline Parameter (unit of measure) & Patient & $\begin{array}{l}\text { Normal } \\
\text { ranges }\end{array}$ \\
\hline Blood count & Normal & \\
\hline $\operatorname{lgM}(\mathrm{mg} / \mathrm{dL})$ & 79 & $40-230$ \\
\hline $\lg G(\mathrm{mg} / \mathrm{dL})$ & 804 & $700-1600$ \\
\hline $\lg \mathrm{A}(\mathrm{mg} / \mathrm{dL})$ & 364 & $70-400$ \\
\hline $\lg \mathrm{E}(\mathrm{mg} / \mathrm{dL})$ & 170 & $<100$ \\
\hline C3 (mg/dL) & 130 & $90-180$ \\
\hline $\mathrm{C} 4$ (mg/dL) & 15 & $10-40$ \\
\hline \multicolumn{3}{|l|}{ Inflammatory markers } \\
\hline ESR $(\mathrm{mm} / \mathrm{h})$ & 37 & $0-15$ \\
\hline $\mathrm{RCP}(\mathrm{mg} / \mathrm{dL})$ & 0.30 & $0-0.50$ \\
\hline Fibrinogen (mg/dL) & 270 & $150-350$ \\
\hline Rheumatoid factor (IU/mL) & 7.8 & $0-8.0$ \\
\hline \multicolumn{3}{|l|}{ Autoimmune profile $\$$} \\
\hline ANCA screening & Negative & Negative \\
\hline p-ANCA (EU/mL) & Negative & $0-0.5$ \\
\hline C-ANCA (EU/mL) & Negative & $0-0.5$ \\
\hline ANA & Negative & $<1: 40$ \\
\hline ENA & Negative & $<1.20$ \\
\hline nDNA & Negative & $<1: 10$ \\
\hline Anticardiolipin Abs & Negative & Negative \\
\hline $\operatorname{TgAb}(\mathrm{IU} / \mathrm{mL})$ & 15.5 & $0-115.0$ \\
\hline TPOAb (IU/mL) & 39.5 & $0-34.0$ \\
\hline TRAB (IU/mL) & 2.6 & $0-1.0$ \\
\hline $\operatorname{lgA}$ tTG (IU/mL) & 1.6 & $<7$ \\
\hline $\operatorname{lgG}$ tTG (IU/mL) & 3.4 & $<7$ \\
\hline IgA EMA & Negative & Negative \\
\hline PCA & Negative & Negative \\
\hline GAD (IU/mL) & $<1$ & $<1$ \\
\hline ICA & Negative & Negative \\
\hline St-C-Abs & Negative & Negative \\
\hline
\end{tabular}

* Boldface values indicate abnormality. ${ }^{\S} \mathrm{p}$ - and c-ANCA: perinuclear and classic anti-neutrophil cytoplasmic antibodies. ANA: anti-nuclear antibodies; ENA: anti-extractable nuclear antigens antibodies; n-DNA: anti-native DNA. TgAb: thyroglobulin antibodies. TPOAb: thyroid peroxidase antibodies. TRAb: TSH receptor antibodies tTG: anti-tissue transglutaminase antibodies. EMA: anti-endomysial antibodies. PCA: anti- gastric parietal cell antibodies. GAD: anti-glutamic acid decarboxylase antibodies. ICA: anti-islet cell antibodies. St-C-Abs: anti-steroid-cell antibodies. Anticardiolipin Abs, ANA, ENA, n-DNA, tTG, PCA, St-C-Abs were assayed by indirect immunofluorescence (IIF). p- and c-ANCA were assayed by both IIF and ELISA techniques. TgAb, TPOAb, TRAb and GAD were measured by immunoradiometric assay. EMA were assayed by ELISA.
Table 2. Thyroid function tests and thyroid autoantibodies of the patient at the time of the second episode of urticaria, and six months after that*

\begin{tabular}{lccc}
\hline $\begin{array}{l}\text { Parameter" } \\
\text { of measure) }\end{array}$ & At admittance & $\mathbf{6}$ months later & Normal ranges \\
\hline TSH (mU/L) & 0.35 & $<\mathbf{0 . 0 0 5}$ & $0.27-4.2$ \\
FT3 (pg/mL) & 3.66 & $\mathbf{3 2 . 5 2}$ & $2.0-4.4$ \\
FT4 (pmol/L) & 16.96 & $\mathbf{7 . 2 1}$ & $12-22$ \\
TgAb (IU/mL) & 15.5 & $\mathbf{1 4 5 . 5}$ & $0-115.0$ \\
TPOAb (IU/mL) & $\mathbf{3 9 . 5}$ & $\mathbf{2 3 5 . 5}$ & $0-34.0$ \\
TRAB (IU/L) & $\mathbf{2 . 6}$ & $\mathbf{1 0 . 1 0}$ & $0-1.0$ \\
\hline
\end{tabular}

* Boldface values indicate abnormality.

"FT4: free thyroxine; FT3: free triiodothyronine; TSH: thyroid stimulating hormone. Serum FT4, FT3 and TSH concentrations were measured by immunoenzymatic methods (commercial kits by Medical Systems [Genoa, Italy]). Thyroglobulin antibodies (TgAb) and thyroid peroxidase antibodies (TPOAb) were measured by the corresponding immunoradiometric assay kit by DiaSorin (Saluggia, Italy). TSH receptor antibodies (TRAb) were measured by using a secondgeneration radioreceptor assay (Dynotest TRAK Human; B.R.A.M.S., Henningsdorf, Germany).

\section{DISCUSSION}

We have reported here the case of a woman with Graves' disease, chronic spontaneous urticaria and autoimmune premature ovarian failure that developed almost simultaneously. Thus, this patient may be classified as having an autoimmune polyglandular syndrome (APS). Reviewing the literature pertaining to the phenotypes of the adult forms of APS (15), the association of these three autoimmune diseases has not been reported yet. Indeed, CSU has been frequently reported in the APS type 3 , namely the $3 \mathrm{C}$ phenotype in which an autoimmune thyroid disease (either GD or HT) is associated with non-endocrine (i.e. cutaneous, neurological and/or haematological) disorders (11). Ovarian failure may be associated with adrenal autoimmunity and Addison's disease (APS type 1 and 2) or with thyroid autoimmunity (APS type 3A) (15). To our knowledge, no reports are available in the literature on the association between POF and CSU in the context of APSs. Thus, our report appears to be original, emphasizing how the combination/association between endocrine and non-endocrine autoimmune diseases may vary and APSs type 3 still represent "an expanding galaxy" (15). The genetic background of such unusual association is a specific combination of HLA haplotypes. It is well known that genetic factors underlie many autoimmune disorders, and an association with specific antigens of the major complex of histocompatibility has been frequently found (16). For CSU, an association with HLA-DR4 has been reported (9). A strong association of GD with HLA-DR3 (HLA DRB1*0301) has been observed in Caucasian subjects, and more recent studies indicate that HLA-DR3 is in strong linkage dis- 
Table 3. Genomic and serological human leukocyte antigens (HLA) haplotype of our patient\$

\begin{tabular}{|c|c|c|c|c|c|}
\hline & \multicolumn{5}{|c|}{ HLA loci } \\
\hline & HLA-A & HLA-B & HLA-Cw & HLA-DRB & HLA-DQ \\
\hline Genomic & *24:02/*26:01 & ${ }^{*} 08: 01 /{ }^{*} 44: 02$ & ${ }^{*} 07: 01 /{ }^{*} 12: 03$ & $\begin{array}{l}\mathrm{B} 1^{*} 03: 01 /{ }^{*} 11: 01 \\
\mathrm{~B} 3{ }^{*} 03: 06 / 03: 06\end{array}$ & $\begin{array}{l}\mathrm{A} 1{ }^{*} 05: 01 /{ }^{*} 05: 01 \\
\mathrm{~B} 1{ }^{*} 02: 01 /{ }^{*} 03: 01\end{array}$ \\
\hline Serological & 24(9)/26(10) & $8 / 44(12)$ & $7 /-\mathrm{a}$ & $\begin{array}{c}17(3) / 11(5) \\
52\end{array}$ & $2 / 7(3)$ \\
\hline
\end{tabular}

§We studied HLA expression on lymphocytes of our patient by both a serological and a molecular approach, employing the micro-lymphocytotoxicity test (Biotest AG, Dreieich, Germany) and the

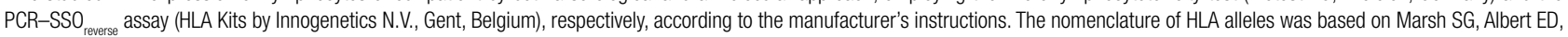
Bodmer WF, et al. Nomenclature for factors of the HLA system, 2010. Tissue Antigens 2010;75:291-455 (www.ebi.ac.uk/imgt/hla/).

aThe minus sign indicates "not expressed".

equilibrium with $\mathrm{DQB1}{ }^{*} 0201$ and $\mathrm{DQAl}{ }^{*} 0501$, both of which are strongly associated with Graves' disease (10-12). Finally, the DRB1*11/ DQB1*0301 genotype is associated with aPOF $(13,14)$. Thus, the HLA haplotype of our patient (see Table 3 ) is consistent with those frequently found in these autoimmune disorders and confers genetic susceptibility to all three diseases.

Besides the genetic background, we believe that there is a pathogenic link between the three diseases. From the lesson learned with other autoimmune diseases, a reaction against a common antigen shared by the involved tissue, autoantibodies targeting similar epitopes or a cross-reaction between autoantibodies may be hypothesized. For instance, Altrichter and cols. have recently demonstrated that a sizeable subgroup of CSU patients exhibits IgE antibodies against thyroid peroxidase. These IgE-anti-TPO autoantibodies, when bound to the $\mathrm{IgE}$ receptor on the surface of mast cells, could cause mast cell activation and degranulation, thus playing an active role in the pathogenesis of CSU (17). Moreover, increased serum levels of $\mathrm{IgE}$ have been reported in one third of GD patients, and serum levels of TRAb are significantly related with total $\operatorname{IgE}$, suggesting that a close cross-talk between the allergic and immune reactions exist in GD $(18,19)$.

Another important finding of our report is the clinical evidence of improvement of CSU when thyroid function was restored. In our case, the first manifestations of CSU appeared while the patient was hyperthyroid, before starting MMI, and were poorly responsive to antihistamine therapy alone. During MMI therapy, CSU quickly improved as thyroid function normalized, and become responsive to standard antihistamine treatment. Few years later, during a period of increased stress, the patients experienced again urticarial symptoms, and within six months of the onset of urticaria, hyperthyroidism recurred. Once again, urticaria im- proved significantly as thyroid function recovered with methimazole. A similar improvement in skin manifestations of CSU after therapeutic correction of hyperthyroidism has been reported by other authors (20-22). Unfortunately, these are anecdotal reports regarding only one or a few number of patients, so they do not enable us to establish the real role of anti-thyroid drugs on the course of urticaria. Obviously, the amelioration of urticarial symptoms observed may be a result of the reduction in sweating, itching, and heat intolerance experienced by the patient when hyperthyroidism was corrected. However, anti-thyroid drugs not only decrease the synthesis (and serum levels) of thyroid hormones, but they may also exert immunosuppressive effects, that contribute to GD remission (23). It is also conceivable that they may influence the course of CSU of autoimmune origin. In our patient, improvement of urticaria was associated with a decrease of serum levels of TPO-Ab and TRAb that persisted negative during remission. When CSU recurred, a rise in TPOAb and TRAb titers was noted.

In conclusion, the main findings of this report are the coexistence of GD, CSU, and POF, which have not been previously reported; the detection of a haplotype associated with susceptibility to all three diseases; and the clinical evidence of improvement of CSU when thyroid function was restored.

Disclosure: no potential conflict of interest relevant to this article was reported.

\section{REFERENCES}

1. Zuberbier T, Asero R, Bindslev-Jensen $C$, Church Mk, GiménezArnau A, Grattan CE, et al. EAACl/GA(2)LEN/EDF/WAO guideline: definition, classification and diagnosis of urticaria. Allergy. 2009;64:1417-26.

2. Maurer $M$, Weller $K$, Bindslev-Jensen $C$, Giménez-Arnau $A$, Bousquet PJ, Bousquet $\mathrm{J}$, et al. Unmet clinical needs in chronic 
spontaneous urticaria. A GA2LEN task force report. Allergy. 2011;66:317-30.

3. Sabroe R, Poon E, Orchard G, Lane D, Francis DM, Barr RM, et al. Cutaneous inflammatory cell infiltrate in chronic idiopathic urticaria: comparison of patients with and without anti-FcERI or anti-IgE antibodies. J Allergy Clin Immunol. 1999;103:484-93.

4. Bagnasco M, Minciullo PL, Saraceno GS, Gangemi S, Benvenga S. Urticaria and thyroid autoimmunity. Thyroid. 2011;21(4):401-10.

5. Gangemi S, Saitta S, Lombardo G, Patafi M, Benvenga S. Serum thyroid autoantibodies in patients with idiopathic either acute or chronic urticaria. J Endocrinol Inves. 2009;32(2):107-10.

6. Ruggeri RM, Imbesi $S$, Saitta $S$, Campennì $A$, Cannavò $S$, Trimarchi F, et al. Chronic idiopathic urticaria and Graves' disease. J Endorinol Invest. 2013;36(7):531-6.

7. Confino-Cohen R, Chodick G, Shalev V, Leshno M, Kimhi O, Goldberg A. Chronic urticaria and autoimmunity: associations found in a large population study. J Allergy Clin Immunol. 2012;129 (5):1307-13.

8. Sabroe RA, Grattan CE, Francis DM, Barr RM, Kobza-Black A, Greaves MW. The autologous serum skin test: a screening test for autoantibodies in chronic idiopathic urticaria. $\mathrm{Br} \mathrm{J}$ Dermatol. 1999;140 (3):446-52.

9. Bozek A, Krajewska J, Filipowska B, Polanska J, Rachowska R, Granzka $A$, et al. HLA status in patients with chronic spontaneous urticaria. Int Arch Allergy Immunol. 2010;153(4):419-23.

10. Barlow $A B T$, Wheatcroft N, Watson $P$, Weetman AP. Association of HLA-DQA*0501 with Graves' disease in English Caucasian men and women. Clin Endocrinol. 1996;44 (1):73-7.

11. Zamani M, Spaepen M, Bex M, Bouillon R, Cassiman JJ. Primary role of the HLA class II DRB $1 * 0301$ allele in Graves' disease. Am J Med Genet. 2000;95(5):432-7.

12. Ramos Lopez E, Fernandez-Balsells M, Kahles H, Seidl C, Ferrer J, Badenhoop K. HLA-DQ haplotypes in Spanish and German families with Graves' disease: contribution to DQA1*0501DQB $1 * 0301$ mediated genetic susceptibility from fathers. Thyroid. 2007;17(11):1131-5.

13. Arif $\mathrm{S}$, Underhill JA, Donaldson P, Conway GS, Peakman M. Human leukocyte antigen-DQB $1{ }^{*}$ genotypes encoding aspartate at position 57 are associated with 3b-hydroxysteroid dehydrogenase autoimmunity in premature ovarian failure. J Clin Endocrinol Metab. 1999;84(3):1056-60.

14. Ferraù F, Gangemi S, Vita G, Trimarchi F, Cannavò S. Pregnancy after azathioprine therapy for ulcerative colitis in a woman with autoimmune premature ovarian failure and Addison's disease: HLA haplotype characterization. Fertil Steril. 2011;95(7):2430.e15-7.

15. Betterle C, Presotto F. Autoimmune polyendocrine syndromes (APS) or multiple autoimmune syndrome (MAS). In: Walker S, Jara LJ, editors. Handbook of systemic autoimmune diseases. Endocrine manifestations of systemic autoimmune diseases. Amsterdam: Elsevier; 2008, p. 135-48.

16. Thorsby E, Lie BA. HLA associated genetic predisposition to autoimmune diseases: genes involved and possible mechanisms. Transpl Immunol. 2005;14(3-4):175-82.

17. Altrichter S, Peter HJ, Pisarevskaja D, Metz M, Martus P, Maurer $M$. IgE mediated autoallergy against thyroid peroxidase--a novel pathomechanism of chronic spontaneous urticaria? PLoS One. 2011;6(4):e14794.

18. Komiya I, Yamada T, Sato A, Kouki T, Nishimori T, Takasu N. Remission and recurrence of hyperthyroid Graves' disease during and after thiamazole treatment when assessed by lgE and interleukin 13. J Clin Endocrinol Metab. 2001;86(8):3540-4.

19. Yamada T, Komiya I, Miyahara Y, Komatsu M, Shima I, Inazawa T, et al. Effect of methimazole treatment for 2 years on circulating IL-4, IgE, TBII, and TSAb in patients with hyperthyroid Graves' disease. Endocr J. 2006;53(6):783-8.

20. Henderson CA, Highet AS. Urticaria associated with thyrotoxicosis. Clin Exp Dermatol. 1995;20(2):173-4.

21. Gaig P, García-Ortega P, Enrique E, Richart C. Successful treatment of chronic idiopathic urticaria associated with thyroid autoimmunity. J Investig Allergol Clin Immunol. 2000;10(6):342-5.

22. Bansal AS, Hayman GR. Graves' disease associated with chronic idiopathic urticaria: 2 case reports. J Investig Allergol Clin Immunol. 2009;19(1):54-6.

23. Cooper DS. Antithyroid drugs. N Engl J Med. 2005;3(9):905-17. 